\title{
Padre Gay: um cônego ilustrado na campanha gaúcha
}

\author{
Priest Gay: a canon learned in the \\ gaucho countryside
}

\author{
Beatriz Teixeira Weber* \\ Jaisson Oliveira da Silva**
}

\begin{abstract}
Resumo: O presente artigo é uma reflexão sobre o padre João Pedro Gay, que atuou em Alegrete e Uruguaiana, de 1848 a 1891, como sacerdote secular. A documentação utilizada faz parte dos seus registros pessoais, encontrados no arquivo do Instituto Histórico e Geográfico Brasileiro. Suas atividades foram diversificadas. Destaca-se seu exercício da homeopatia no interior do Rio Grande do Sul.
\end{abstract}

Palavras chave: Clero, História da homeopatia, Rio Grande do Sul, Arquivo privado

Abstract: The present article is a reflexion about the priest João Pedro Gay, that worked in Alegrete and Uruguaiana from 1848 to 1891, as a secular clergyman. The documentacion used is part of yours personal records, found at the filing department of the Instituto Histórico e Geográfico Brasileiro. Your activities were diversifies. We detach your performed with homeopathy in the interior of the Rio Grande do Sul.

Keywords: clergy, homeopathy history, Rio Grande do Sul, private file

\section{Introdução}

João Pedro Gay foi um dos responsáveis pela introdução da homeopatia no Rio Grande do Sul no século XIX. Seu acervo documental está preservado no Instituto Histórico e Geográfico Brasileiro, constando

* Professora associada Departamento de História da UFSM E-mail: beatriztweber@ gmail.com>.

** Doutorando em História/UFRGS na linha de Teoria da História e Historiografia. Bolsista da Capes. E-mail: <jaissonpj@gmail.com> 
registros pessoais diversos, rascunhos do que estava estudando, sermões, correspondência, dentre uma grande variedade de material que faz referência à história do Rio Grande do Sul. Boa parte da documentação do padre Gay no Instituto não parece ter sido pesquisada, constando de um total de 412 pastas.

A partir da documentação encontrada no IHGB, os objetivos iniciais do projeto que originou este artigo eram bastante amplos: caracterizar a vida no interior do Rio Grande do Sul, através do olhar de um padre secular que atuou no estado na segunda metade do século XIX. Assim como analisar as relações entre homeopatia e demais práticas de cura no Rio Grande do Sul, através da perspectiva desse pároco estrangeiro. Essa amplitude possibilitava que a documentação trabalhada fosse explorada de diversas formas, o que permitia uma série de olhares sobre um personagem quase esquecido na historiografia. A complexidade apresentada pelo personagem e as várias circunstâncias em que ele atuou nos mostraram um vasto campo de reflexão, que foi se constituindo entre as evidências e os conceitos (THOMPSON, 1981, p. 48-54). Neste projeto optamos por transcrever o conjunto de documentos que utilizamos aqui ${ }^{1}$, pois era a documentação que fazia referência específica para os interesses mais gerais do trabalho sobre a história das práticas de cura no Rio Grande do Sul.

A trajetória do padre Gay, ou simplesmente "Cônego Gay", como ficara mais conhecido, ao oposto da de vários líderes e intelectuais atuantes da província na época, foi, por bastante tempo, deixada de lado. Os muitos vazios e incoerências de informações sobre sua vida e obra nos atestam esse desconhecimento. Paradoxalmente, podemos afirmar que também seriam muitos os possíveis questionamentos historiográficos que poderiam conduzir até sua figura, na medida em que sua atuação foi substancial em diversos campos: questões relacionadas à administração local, história eclesiástica, produção historiográfica relacionada às missões, estudos geográficos, estudos lingüísticos relacionados aos indígenas, história política da província, descrição de plantas e suas aplicações na prática homeopática no Brasil imperial. Este breve artigo se propõe a sintetizar os resultados de uma trajetória investigativa, que

\footnotetext{
Mais especificamente uma série de documentos da pasta 24, lata 406, que constituem um caderno de rascunho denominado Livro manuscrito: rascunho de cartas sobre administração dirigidas de Alegrete e de S. Borja. 1848/1858. Os documentos foram transcritos e optou-se por atualizar a ortografia para facilitar a leitura. O restante da documentação levantada encontra-se no Centro de Documentação Histórica do Departamento de História da UFSM.
} 
procurou seguir o encalço deste vigário tão singular e decisivo nas disputas políticas e religiosas do Rio Grande do Sul no século XIX. Esta pesquisa contou com o apoio financeiro do CNPq no levantamento das fontes no ano de 2005 e no desenvolvimento da transcrição e na análise do material de 2007 a 2009.

\section{Algumas considerações biográficas}

A falta de pesquisas sobre a vida do padre Gay e sua obra faz de um estudo como este uma tarefa espinhosa. Procuramos seguir as pistas dos pequenos resumos biográficos encontrados e a primeira constatação foi com relação à incompatibilidade dos dados, datas e mesmo locais onde teria atuado. O primeiro resumo biográfico foi escrito ainda no século XIX, a compilação bibliográfica de Augusto Victorino Blake (BLAKE, 1898, p.19-20), provavelmente baseado, pelo menos em parte, no breve prefácio do cônego Fernandes Pinheiro à primeira edição da História da República Jesuitica do Paraguai (GAY, 1863)². O resumo de Blake traz informações mais pontuais, que parecem constituir o panorama mais comum em relação aos aspectos balizares da trajetória biográfica do padre Gay, como suas datas de nascimento e morte e os locais onde atuou. Tais informações correspondem também às apresentadas por Rodolfo Garcia, em seu prefácio à reedição de 1942 (GARCIA, 1942), realizada sob os auspícios de Getúlio Vargas, de maneira que não há contradições evidentes entre os dados dessa e os das notícias biobibliográficas anteriores.

A última e também mais completa referência que encontramos é o artigo escrito pelo conhecido historiador brasileiro José Honório Rodrigues para o número 19 da Revista Província de São Pedro, datado de 1954 (RODRIGUES, 1954, p. 75-92). Rodrigues parte da crítica aos prefácios da primeira edição - do cônego Fernandes Pinheiro - e da segunda - de Rodolfo Garcia - apontando o fato de terem praticamente ignorado um manuscrito autobiográfico e todo o conjunto documental preservado nos arquivos do IHGB. O qual, de acordo com sua argumentação, traz subsídios que contradizem várias das informações tidas com verdadeiras a respeito da vida de Gay. Embora também faça

\footnotetext{
No mesmo ano, foi publicado na Revista do Instituto Histórico e Geográfico Brasileiro, t. XXVI, partes $1^{\mathrm{a}}$ e $2^{\mathrm{a}}$, numa edição com praticamente a metade dedicada ao estudo das missões. Esta é a grande obra sobre a história missioneira escrita por Gay, até hoje umas das principais obras de referência sobre o assunto.
} 
algumas afirmações contestáveis, o resumo de Rodrigues é bem mais completo e documentado que os anteriores.

De acordo com esse historiador brasileiro, o presbítero que veio do seminário de Gap, na região montanhosa dos Alpes, sul da França, chegou ao Brasil após encontrar seu destino inicial - a cidade de Montevidéu - em estado de sítio, em 1842. O jovem padre, que havia recebido a ordenação há pouco mais de dois anos, teria sido apresentado pelo arcebispo de Bordéus ao vigário de Montevidéu para estabelecer uma igreja nesta cidade, que abrigava grande número de imigrantes franceses. Mal sucedida sua primeira tentativa de inserção na América, deslocou-se para a província de Santa Catarina, vindo a assumir, em 1843, posição de vigário encomendado da freguesia de Santa Ana de Vila Nova. Nos resumos de Blake e Garcia, essa freguesia figura como sendo "Santa Ana de Vila Nova de Laguna", mas Rodrigues afirma ser esta "Santa Ana de Vila Nova de Lages". No entanto, ambas parecem errôneas, pois tal freguesia nada tinha a ver com as mencionadas cidades catarinenses, sendo apenas "Santa Ana de Vila Nova", atual município de Imbituba, no estado de Santa Catarina (MARTINS, 2003).

Em setembro do ano seguinte seguiu rumo ao Rio de Janeiro, onde lecionou francês e matemática no Colégio Saraiva e nos anos seguintes realizou seus estudos de homeopatia, formando-se na novíssima Escola Homeopática do Brasil, fundada em 1845 e vinculada ao Instituto Homeopático do Brasil, de 1843 (WEBER, 2008, p.103).

Após a pacificação do conflito farroupilha, foi-lhe determinado reger a freguesia e a vara eclesiástica de Alegrete, no Rio Grande do Sul, em 1848. Pouco depois, tendo sido realizado concurso de vigário colado para esta freguesia, Gay retornou à Corte e nessa ocasião recebeu a carta de cidadão brasileiro (RODRIGUES, 1954, p. 77). Em setembro de 1849, prestou concurso para freguesias vagas e foi nomeado para São Borja, sendo colado vigário a 7 de novembro e assumindo o cargo em 24 de fevereiro de $1850^{3}$.

Em 1861, viajou ao Rio de Janeiro para publicar sua obra sobre as missões e aproveitou para realizar as provas do concurso ao curato do S.S. Sacramento do Rio de Janeiro, cujo resultado lhe concedeu o título de Cônego Honorário da Capela Imperial. Retornou passando por Montevidéu e Buenos Aires. Em junho de 1865 teve o maior prejuízo de sua vida, quando as tropas do Tenente-Coronel paraguaio Antônio

Lata 406. Documento 24. Livro manuscrito: rascunho sobre a administração dirigidas de Alegrete e São Borja. 1848-58. 9 Jan 1851. IHGB. 
Estigarribia invadiram a vila de São Borja e saquearam sua residência, destruindo grande parte de seus manuscritos originais e da sua biblioteca de mais de mil volumes. Deslocou-se, então, para Uruguaiana, de onde retornou em setembro com o exército brasileiro e passou a tentar refazer seus manuscritos.

Em 20 de julho de 1874 foi nomeado vigário de Uruguaiana, local aonde faleceu em maio de 1891 .

\section{Discussões políticas e clericais do padre Gay}

Em meados do século XIX, nas imediações do território missioneiro da Província do Rio Grande do Sul, a presença de um jovem e esclarecido sacerdote passou a despertar curiosidade e angariar algumas animosidades em função de sua pena, que parecia conseguir escrever mais do que a de qualquer tradicional burocrata do governo. Desde que assumiu a vara eclesiástica da freguesia de Alegrete, na fronteira da província sulina, em 1848, o padre francês João Pedro Gay parecia disposto a intervir no destino daqueles povoados que, em tempos de paz, pareciam mais esquecidos do que nunca.

A busca por participar da vida social e política de sua pequena vila e da província rio-grandense foi a principal característica de sua trajetória de vida. A documentação que citamos e com a qual trabalhamos atesta essa sua verve relacional.

Desde seu primeiro ano como cônego oficial de São Borja, sua interação epistolar com as instâncias administrativas da província, incluindo os presidentes provinciais, já foi bastante considerável e sobre variados assuntos. Em novembro de 1850, por ocasião da nomeação de Pedro Ferreira de Oliveira para a presidência da província, padre Gay, recém instalado na vila, lhe mandou uma rebuscada carta, felicitando pela sua chegada ao Rio Grande e tecendo-lhe rasgados elogios ${ }^{4} \mathrm{Na}$ coleção de correspondências que examinamos há várias cartas parecidas, levando felicitações, pedindo verbas, informando da situação das freguesias próximas, etc.

Em pouco tempo ficou bastante conhecido devido à sua capacidade de argumentação e ao seu dilatado campo de relações e contatos. Gay não apenas conheceu e trocou informações com os homens mais influentes da região e da província, como também trocou correspondências pessoais

4 Lata 406. Documento 24. Livro manuscrito: rascunho sobre a administração dirigidas de Alegrete e São Borja. 1848-58. $20 \mathrm{dez}$ 1850. IHGB. 
com o Imperador, o Barão de Rio Branco, o naturalista Aimé Bonpland, o geólogo Nathaniel Plant, com Benjamin Ramiz Galvão e até mesmo com Solano López (RODRIGUES, 1954, p. 78)5.

João Pedro Gay tinha uma visão bastante clara do seu papel como sacerdote e da amplitude das suas atividades como pároco. Ele assumiu como padre na vila de Alegrete em 02 de julho de 1848, logo depois da paróquia ter sido criada em 30 de abril de 1846, substituindo o padre Antônio Gomes do Vale, que foi o primeiro pároco (RUPERT, 1998, p. 80). Quando assumiu, ele tomou as primeiras providências na organização da paróquia, enviando ofício à Câmara Municipal em 23 de setembro de 1848 sobre o arranjo do cemitério. Ele descrevia que o cemitério estaria em um terreno inadequado, cheio de águas e de pedra, com os corpos cobertos apenas com alguns palmos de terra, exalando um cheiro pestífero nas proximidades, com ossos e cinzas misturados dos enterrados no lugar. Pedia uma subscrição à Câmara Municipal para a construção de um novo cemitério em lugar mais "convenientemente salubre".

A argumentação utilizada pelo padre revela uma formação bastante erudita. Para justificar seu pedido à Câmara Municipal, ele reconstituía a história da igreja e os costumes de gregos e romanos, além de argumentar sobre a precariedade das condições existentes e da necessidade da defesa da proposta que estava fazendo. Gay se incumbia do papel de um pároco com responsabilidades sociais bem definidas na defesa do rebanho de Deus, função que estendia até para pedir medidas aos responsáveis pelas obras públicas do município. Em ofício ao Presidente da Província de 12 de setembro de 1848, ao mandar os mapas estatísticos da população da província, aproveitou para fazer uma observação a respeito dos óbitos, que seriam em pouco número, pois em quase todas as fazendas do município haveria cemitérios particulares, onde sepultariam os defuntos sem notificarem aos vigários nem a nenhuma autoridade. O mesmo aconteceria na vila de Alegrete, porque o cemitério estava aberto e qualquer indivíduo iria cavar uma cova para sepultar um defunto ${ }^{7}$. Entendia que sua obrigação como pároco estendia-se em notificar as irregularidades às autoridades competentes, para que elas tomassem

Lata 406. Documento 24. Livro manuscrito: rascunho sobre a administração dirigidas de Alegrete e São Borja. 1848-58. Há variadas cartas que citam estes nomes, além de outros que não citamos.

6 Lata 406. Documento 24. Livro manuscrito: rascunho sobre a administração dirigidas de Alegrete e São Borja. 1848-58. 12 e 23 set 1848. IHGB.

7 Lata 406. Documento 24. Livro manuscrito: rascunho sobre a administração dirigidas de Alegrete e São Borja. 1848-58. 12 set 1848. A organização dos ofícios não está em ordem de data. IHGB. 
medidas cabíveis. Seu papel social ia além do atendimento espiritual dos paroquianos.

Além dessa, sua intervenção foi significativa em muitos outros momentos. Citamos agora uma das mais expressivas.

A delimitação dos limites municipais entre São Borja e Itaqui ${ }^{8}$ remonta à época da chegada do cônego francês. Ao saber das intenções da Paróquia de Itaqui em querer anexar os distritos de São Francisco de Assis e São Xavier, até então pertencentes a São Borja, padre Gay iniciou uma batalha contra essa iniciativa, usando todo seu poder argumentativo e o enorme conhecimento que possuía sobre a região. Esta parece ser umas das primeiras grandes questões em que se envolveu? ${ }^{9}$.

Em muitos dos documentos percebemos seu tom diplomático, mas também ameaçador, no sentido de ter posições firmes e ímpeto para levar tais pendengas até as autoridades máximas se fosse necessário. Sobre esta questão, três dias antes ele havia escrito uma extensa carta ao Presidente da Província, expondo o problema usando uma retórica polida e lançando mão de argumentos geográficos, históricos e etnográficos. A disputa foi muito marcada pela rixa que mantinha com o vigário de Itaqui, padre Passos, autor da requisição de anexação e seu antecessor na paróquia de São Borja. Gay estava, evidentemente, consciente das dificuldades que poderiam advir da considerável diminuição de fiéis ligados a São Borja, caso essa incorporação se confirmasse. Comentava sobre esse risco na correspondência que enviou à Câmara, mas não deixou de enfatizar que seu pedido era em função dos moradores, que, conforme argumentava, eram na maioria contrários a tal alteração, visto que teriam enormes dificuldades de deslocamento caso a mudança fosse efetivada.

Neste ínterim, não deixou de fazer valer as amizades que possuía. Pouco tempo depois se correspondeu com Luiz Manoel Menezes da Silva, chefe de engenheiros e topógrafo, pedindo para que este usasse sua "mais alta ilustração" e seus "altos conhecimentos profissionais" para informar o Presidente da Província da posição topográfica dos lugares indicados com relação a $\mathrm{S}$. Borja e Itaqui ${ }^{10}$.

No mês seguinte, oficializou de vez o conflito com o vigário de Itaqui, explicando a situação em correspondência ao bispo e afirmando querer o tal vigário Passos roubar-lhe seu lugar em São Borja. Seu pedido

8 Que no momento eram apenas freguesias e, portanto, as disputas se deram em torno da anexação das paróquias.

9 Lata 406. Documento 24. Livro manuscrito: rascunho sobre a administração dirigidas de Alegrete e São Borja. 1848-58. 12 jan 1851. IHGB.

${ }^{10}$ Lata 406. Documento 24. Livro manuscrito: rascunho sobre a administração dirigidas de Alegrete e São Borja. 1848-58. 25 abr 1851. IHGB. 
termina com uma solicitação para que fosse aberto concurso à freguesia de Itaqui, que, devido sua importância nas missões, não poderia ter um pároco encomendado que realizasse tamanhas intrigas. Uma carta subseqüente ao mesmo bispo explicava novamente a situação, afirmando que o padre Passos, tão logo assumiu por encomenda a freguesia de Itaqui, requisitou a anexação dos citados distritos à Presidência da Província que, por sua vez, consultou a câmara de São Borja. Esta, numa sessão em que havia vários suplentes, na qual a maioria era de amigos ou parentes de Passos, acatou o pedido de anexação ${ }^{11}$.

$\mathrm{O}$ embate tornou-se áspero ao ponto do padre Gay registrar queixa com o delegado local por ter o vigário de Itaqui ministrado sacramentos em território que ainda pertenciam a São Borja. Nesse episódio, enviou correspondências ao delegado, ao Presidente de Província, ao vigário geral da província, e ao próprio pároco de Itaqui, em forma de protesto. Ao que parece, a questão permaneceu por algum tempo viva, sendo que, em 1853, Gay decidiu requerer à Assembléia Legislativa Provincial que os ditos distritos tivessem suas próprias paróquias ou capelas-curadas, aparentemente num último esforço para não entregá-las à Itaqui ${ }^{12}$.

Não há muitos registros ulteriores, ao menos na documentação analisada, dos desdobramentos da questão, mas sabemos que, em 1858, o padre Gay remeteu à Assembléia Provincial um abaixo assinado de famílias "dos Três Povos" agradecendo pela resolução que "os fez pertencer ao Município de São Borja"13. Poucos meses depois, em dezembro, Itaqui foi oficialmente desmembrada de São Borja, mas tendo sob seu domínio eclesiástico apenas a freguesia de São Francisco de Assis.

Um outro ponto importante na discussão que Gay participa é a questão fronteiriça. Padre Gay tinha um conhecimento invejável da formação geográfica da região, não só por suas andanças, como também pelas informações que colhia de viajantes das imediações ${ }^{14}$.

${ }^{11}$ Lata 406. Documento 24. Livro manuscrito: rascunho sobre a administração dirigidas de Alegrete e São Borja. 1848-58. $1^{\circ}$ jul 1851. IHGB.

${ }^{12}$ Lata 406. Documento 24. Livro manuscrito: rascunho sobre a administração dirigidas de Alegrete e São Borja. 1848-58. 15 abr 1853. IHGB.

${ }^{13}$ Lata 406. Documento 24. Livro manuscrito: rascunho sobre a administração dirigidas de Alegrete e São Borja. 1848-58. 10 set 1858. IHGB.

${ }^{14}$ Há referências de que teria acolhido em sua residência e trocado informações com Robert Christian Berthold Avé-Lallemant (1812-1884), cronista alemão, autor de Viagem pela Província do Rio Grande do Sul, publicado na Alemanha em 1859. "Médico alemão, residiu no Brasil por cerca de vinte anos e visitou o Rio Grande do Sul em 1858. Suas descrições da paisagem, fauna, flora, economia, vida social e usos e costumes da população estavam relacionadas a um objetivo maior, que era o de divulgar, na Europa os avanços e perspectivas da colonização alemã." (TORRES, 1997, p. 45-47). 
Rodrigues menciona o ofício de "extraordinária importância” que Gay escreveu acerca do tratado de limites de 1858, avisando ao governo provincial sobre uma faixa de território que não fora considerada nos tratados, que era desabitada e também desconhecida pelos castelhanos e, provavelmente, povoada por bugres hostis (RODRIGUES, 1954, p. 81 $)^{15}$. Tal ofício, endereçado ao presidente Ângelo Muniz da Silva Ferraz e, mais ainda, o indício de um ofício de resposta da presidência lhe enviando os tratados e solicitando maiores informações acerca do assunto, indicam a participação efetiva de Gay nessa questão política. Ele inclusive se permitiu sugerir ao governo que "homens corajosos", "nossos sertanejos", poderiam, com auxílio provincial, estabelecer povoações permanentes na região, como forma de fazer valer o chamado direito de uti possidetis do Império ${ }^{16}$.

Igualmente, há outras correspondências nas quais o cônego de São Borja traçou relatórios sobre as condições das igrejas dos antigos povos missioneiros e relatou os freqüentes roubos às construções antigas; há também documentos como um detalhado levantamento geológico que envia à presidência dissertando sobre as riquezas minerais da região ou, ainda, alguns sermões que pronunciava em suas missas e que mantinha organizados em seu arquivo, bem como os manuscritos de seus inúmeros estudos, que comentamos a seguir.

\section{A "enciclopédia viva" da fronteira: as ciências do padre Gay}

"O padre Gay era, sem favor, a enciclopédia viva da região". Rodrigues certamente foi feliz nessa denominação, porque ela traduz muito do que representou esse cônego ilustrado na região da campanha gaúcha em pleno século XIX: "um erudito, um grande curioso" (RODRIGUES, 1954, p. 77, p. 83).

Podemos, sem hesitar, endossar o argumento de Rodrigues. O seu ideal de ilustração levou Gay a cultivar o conhecimento de tantos assuntos quantos fossem necessários para dar vazão ao seu sentimento de pertencimento àquele território e ao senso de responsabilidade que

${ }^{15}$ Embora Rodrigues cite-o como sendo de 9 de novembro, encontramos na documentação exatamente o mesmo ofício que cita, mas com data de 19 de agosto. Há também uma carta subseqüente, que seria a réplica à resposta do referido ofício, que confirma ser aquele de 19 de agosto. A localização que Rodrigues cita também não é a mesma da documentação que averiguamos, muito embora o conteúdo seja exatamente o mesmo citado por ele. Lata 406. Documento 24. Livro manuscrito: rascunho sobre a administração dirigidas de Alegrete e São Borja. 1848-58. 19 ago 1858. IHGB.

${ }^{16} \mathrm{Ou}$ seja, o direito de posse sobre os territórios que já estivessem colonizados. 
nutria para com aquelas terras e pessoas. Esse sentimento estava evidente em sua obstinação por conhecer e fazer conhecer aquela terra, sendo que para isso precisou estudá-la a fundo, em seus aspectos naturais e históricos, humanos e físicos. Seus estudos geraram obras como a História da República Jesuítica do Paraguai, ou ainda seu dicionário comentado da língua tupi em quatro idiomas, ou a História da Guerra do Paraguai, sem contar os compêndios de história natural e os textos esparsos que acabaram se perdendo no já citado episódio da tomada de São Borja pelos paraguaios.

Sua obra histórica sobre as missões é ainda hoje considerada referência basilar para os estudos da formação histórica do Rio Grande do Sul. Gay não se limitou a produzir uma compilação de informações já existentes, muito embora tenha lido as principais obras de história rio-grandense da época, como os Anais da Província de São Pedro, de José Feliciano Pinheiro (1946), e textos de Robert Southey, Varnhagen, e alguns autores platinos. Gay propôs fazer um levantamento de fontes orais e escritas sobre as missões e teve uma frutífera experiência de campo, relacionando-se com as populações indígenas que habitavam a campanha na época e acumulando um grande saber etnográfico e lingüístico sobre esses povos.

Sua obra, de acordo com Torres, partilhava de uma visão jesuítica e sua descrição dos povos indígenas foi feita com base em "conceitos do ideário sociopolítico europeu" a partir da perspectiva evangelizadora das missões jesuíticas (TORRES, 1997, p. 50-53). Como bem pontuou Torres, a concepção que Gay tinha dos povos indígenas não correspondia à historicidade concreta destes. A formação intelectual do padre Gay está relacionada às dimensões sociocultural e ideológica da época em que viveu e da sua inserção religiosa, pois ele era um missionário que tinha vindo de fora no intuito de "promover a fé cristã". A observação que fazia sobre a organização desses povos era permeada por seu ideário religioso e se encontrava dentro dos padrões de compreensão possíveis do período.

Apesar disso, suas obras são referenciadas até hoje nos estudos da língua tupi-guarani. Ele escreveu uma pequena gramática, um dicionário traduzindo a linguagem indígena para quatro idiomas e ainda um vocabulário da língua dos chamados "bugres coroados". Além dessa, sua produção sobre geografia e geologia lhe autorizou a escrever diversos textos sobre minerais, formação hidrográfica e topografia da região da campanha, muitos dos quais lhes eram solicitados pela administração provincial, como já citamos anteriormente. 
A grande diferença temporal entre sua primeira publicação (1863) e a segunda (1942) indica que sua obra fora deixada de lado por bastante tempo e pouco considerada na historiografia rio-grandense, possivelmente pela atenção que dá à atuação jesuítica - sua orientação era contrária à "prática pombalina antijesuítica" de fins do XIX e ao discurso historiográfico nacionalista dos anos 20 e 30 do século XX, interesses preocupados em expurgar a influência do platinismo nas interpretações da história sul-rio-grandense (GUTFREIND, 1998).

E, por último, citamos o aspecto que nos levou a essa pesquisa, a questão da homeopatia ${ }^{17}$.

Gay possivelmente fez parte das primeiras turmas que se formaram no curso de Homeopatia na Escola Homeopática do Brasil, criado em 1845 , quando a homeopatia ainda vivia sua fase de implantação no Rio de Janeiro (WEBER, 2008, p. 103). A propaganda homeopática no Brasil começou com o Dr. Bento Mure ${ }^{18}$, médico francês que veio para o Rio em 1840 - ainda que já houvesse manifestações anteriores dessa prática médica no país (GALHARDO, 1928, p. 271-279). Mure teria vindo com a intenção primeira de fundar uma colônia socialista no Brasil ${ }^{19}$, mas acabou tornando-se um dos principais divulgadores da homeopatia no país quando seu projeto da Colônia do Sahy acabou fracassando (GALHARDO, 1928, p. 281) ${ }^{20}$. Com a ajuda do Dr. João Vicente Martins, fundou o Instituto Homeopático Brasileiro, em janeiro

${ }^{17}$ A terapêutica homeopática é um conjunto de preceitos desenvolvidos pelo médico alemão Cristiano Frederico Samuel Hahnemann, que se baseia no postulado de que o doente deve ser tratado com o medicamento capaz de produzir no seu corpo um conjunto de sintomas e sinais semelhantes aos do que ele apresenta. Os princípios foram, em 1810, publicados no seu livro-mestre, Organon da Ciência Médica Racional (nome que foi mudado, na segunda edição, em 1819, para Organon da Arte de Curar) ou Exposição da Doutrina Médica Homeopática. Sua doutrina procurava restabelecer o estado de equilíbrio entre a força vital e o organismo, com a ingestão de uma substância em doses infinitesimais, visando a curar o paciente como um todo e não apenas o vetor da doença. Defendia a idéia da existência de um princípio vital, não comprovável empiricamente por ser imaterial, mas que seria a causa explicativa da atividade que anima todo o organismo. A força vital seria o princípio intermediário entre o corpo físico (princípio material) e o espírito (princípio espiritual) que os ligava. $\mathrm{O}$ estado de saúde seria aquele em que o funcionamento do corpo e do espírito se fizesse harmoniosamente, em equilíbrio com a força vital; o estado de doença seria justamente a perda dessa harmonia (WEBER, 2008, p. 101-102).

${ }_{18}$ Benoit Jules Mure, nascido em 1809, discípulo de Hahnemann e introdutor da homeopatia na França (GALHARDO, 1928, p. 279).

19 Trazendo, para isso, famílias de trabalhadores franceses que formariam uma colônia societária industrial, de acordo com o modelo de Fourier (GALHARDO, 1928, p. 279-281).

20 Pierre-Luc Abramson também menciona essa experiência, comentando sobre as influências de Mure e Michel Derion, que participou também da formação da colônia (ABRAMSON, 1999, p. 205-218). 
de 1843, e uma sucursal na Bahia, em outubro de 1847 (ABRAMSON, 1999, p. 219).

De acordo com o historiador francês Pierre-Luc Abramson, em um estudo dedicado às utopias sociais na América Latina do século XIX, a ligação entre a homeopatia e o fourierismo não era tão incomum, sendo que nos falanstérios-modelo da Europa - tal como o que Mure tentara instalar no norte de Santa Catarina - os médicos homeopatas eram abundantes. $\mathrm{O}$ grande ideal que vinha sendo sistematicamente divulgado pelos periódicos falansterianos franceses era o princípio de buscar um mundo novo, que, entre outras coisas, também significava transformar a velha medicina (ABRANSON, 1999, p. 219). Tal ideal estava diretamente ligado à vinda de Mure para a América, que, de certa forma, atendia ao chamamento falansteriano para que fossem realizadas experiências societárias pelo mundo.

Esse ideário utópico do qual nos fala Abramson continuará presente, ao menos nas décadas iniciais, no principal espaço de estudos da homeopatia no Brasil, que é a Escola Homeopática. Até mesmo em sua ritualística de diplomação estavam presentes estes signos da "missão profética", pois os formandos faziam um juramento de converter o mundo à homeopatia (ABRAMSON, 1999, p. 220). E, de fato, a trajetória posterior de Mure atestará tal comprometimento, haja vista que ainda virá a fundar sociedades homeopáticas no Egito (1853) e em Gênova (1854), após partir do Brasil, em 1848.

Padre Gay vivenciou e participou desse movimento, realizando estudos de homeopatia e tendo sido também professor da Escola Homeopática após diplomar-se pela mesma ${ }^{21}$. Fora aluno de Vicente Martins e provavelmente de Mure. Há menções ao fato de que a escola admitia com bons olhos os vigários que quisessem aprender a doutrina, para que pudessem, ao espalharem-se pelas paróquias das províncias, utilizarem e difundirem os métodos homeopáticos para a cura dos pobres do império (GALHARDO, 1928, p. 318) ${ }^{22}$.

Há também referências à missa rezada no Mosteiro de São Bento em ação de graças ao reconhecimento da Escola Homeopática pelo império, em 1846, demonstrando que pelo menos parte da Igreja mostrava-se

${ }^{21} \mathrm{O}$ que era comum no início, pois o número de profissionais da área aptos a seguirem lecionando no curso era bastante incipiente.

22 Também são citadas algumas das "missões homeopáticas", ou seja, excursões pelas províncias em que médicos se encarregavam de "criar consultórios gratuitos em benefício das classes pobres", nas quais já haveria um bom número de vigários inseridos (GALHARDO, 1928, p. 384). 
favorável a esta doutrina que passava a ocupar um espaço específico no campo da formação médica brasileira do século XIX (GALHARDO, 1928, p. 355).

Frente à preocupação de dar conta das várias responsabilidades de um pároco no interior, Gay se preocupou em diagnosticar as dificuldades e em atuar em várias frentes. Em carta ao bispo de 13 de outubro de 1848, ele afirmava da precariedade nas freguesias da fronteira: as Igrejas estavam em ruínas, não haveriam paramentos nelas, os cemitérios seriam campos abertos, não se celebravam festas, a disciplina eclesiástica estava em abandono e precisaria de muita atividade e de muita paciência, de muita virtude e prudência para poder reanimar essa região ${ }^{23}$. A vila de São Borja possuía 911 casas com 2001 habitantes e a freguesia possuía 1669 casas com 11.718 habitantes, segundo o recenseamento de $1854^{24}$. Já instalado em São Borja, procurou explicar a necessidade de cultos vistosos ao Presidente da Província, para solicitar ajuda para a conclusão da igreja, que se achava iniciada. A falta de uma igreja seria muito perniciosa num município cuja maior parte da população era indígena ou descendente deles. Gay os considerava "rudes", apenas civilizados por jesuítas. Muita ostentação exterior e muitas festas é que iriam instruir esse povo ${ }^{25}$. Somente com intervenções práticas e visíveis seriam conquistados os povos existentes na localidade.

Nesse contexto, padre Gay entendia ter o dever de utilizar a nova prática para tratar essa pobre gente rude. Em outubro de 1849, solicitou autorização ao seu bispo para exercer a medicina homeopática ${ }^{26}$.

O conjunto documental trabalhado também possui notas sobre a indicação de diversas medicações homeopáticas. Ele se preocupava em utilizar uma medicina menos violenta, que não usava dos procedimentos comuns na época, como a purga e a sangria. Ele procurou habilitarse para o exercício do socorro dos paroquianos que precisassem de homeopatia antes de fazer o concurso que o instalou em São Francisco de Borja. Sua preocupação com o socorro aos enfermos era, portanto, anterior às necessidades de socorro e caridade na localidade, mas faz

${ }^{23}$ Lata 406. Documento 24. Livro manuscrito: rascunho sobre a administração dirigidas de Alegrete e São Borja. 1848-58. 13 out 1848. IHGB.

${ }^{24}$ Lata 404. Pasta 16. Protesto contra o abandono de São Borja pelas autoridades responsáveis. 1855. IHGB.

${ }^{25}$ Lata 406. Documento 24. Livro manuscrito: rascunho sobre a administração dirigidas de Alegrete e São Borja. 1848-58. 03 mai. 1850. IHGB.

${ }^{26}$ Lata 404. Documento 11. Pedido de autorização para exercer, na paróquia de São Francisco de Borja onde é vigário, a medicina homeopática que alega ter estudado; notas sobre med. homeopática. 1849. IHGB. 
parte de sua visão como sacerdote, que devia ser caridoso e otimista. Não sabemos se ele foi autorizado a exercer a homeopatia pelo bispo, pois não consta nenhuma correspondência nesse sentido. Ele continuou mantendo contato com João Vicente Martins, primeiro secretário presidente da Escola Homeopática do Brasil, em que não há nenhuma referência a sua prática específica ${ }^{27}$.

Nesse sentido, o padre Gay estava inserido nas discussões existentes sobre a homeopatia no Brasil. Ele não concordava com a proposta de difusão da homeopatia sem uma formação específica que habilitasse os praticantes. $\mathrm{O}$ uso da homeopatia estava bastante difundido através de conjuntos homeopáticos vendidos em farmácias do Rio de Janeiro. Esses conjuntos também podiam ser adquiridos através de pedidos pelo correio, pois eram divulgados em vários jornais da época, com os principais medicamentos para utilização imediata, juntamente com manuais que explicavam a sua utilização. Gay também defendia a realização de experiências para a descoberta de outras medicações homeopáticas. A proposta sistematizada pela Escola Homeopática do Brasil procurava estimular que os indivíduos devidamente formados pela homeopatia deviam pesquisar novas substâncias no Brasil para servirem como novos medicamentos. Essas pesquisas deveriam ser realizadas nos próprios indivíduos sãos para determinar ao que se destinava, segundo os princípios homeopáticos de que a substância pura poderia criar a sua cura. Essas eram as "experiências" que vários homeopatas no país procuravam desenvolver e remeter à Escola. Padre Gay, portanto, estava integrado nessa proposta, provavelmente testando plantas encontradas na região.

Seu abandono das facilidades e comodidades da capital imperial em favor de uma vida bastante simples e isolada no interior de uma província afastada e pobre, permeou grande parte de suas lutas. Muito embora com um consciente teor utópico, parecia ser o que lhe movia nos seus ideais de padre e de ser humano ilustrado. Evidentemente, essa é uma perspectiva que precisa ser também relativizada, o que deixamos para as considerações da última parte.

\section{Considerações a título de conclusão}

Em um artigo publicado pelo Correio do Sul de 28 de Setembro de 1853, um articulista assinado sob o pseudônimo de "Velho Católico"

${ }^{27}$ Lata 406. Documento 24. Livro manuscrito: rascunho sobre a administração dirigidas de Alegrete e São Borja. 1848-58. 1 jul 1851. IHGB. 
desferiu várias críticas aos padres da campanha, chamando-os de avarentos, desmoralizados, desregrados e criminosos. Prontamente, padre Gay, que se sentiu bastante ultrajado com o ofensivo artigo, redigiu uma réplica, como era de seu costume.

Nela o vigário de São Borja tentava demonstrar que a generalização punha em dúvida a totalidade dos clérigos da região, e que isso não seria correto. Muitos padres seguiam as normas de conduta e cumpriam os deveres exigidos pela Igreja. Em oposição aos argumentos do articulista, que acusara também os padres vindos do estrangeiro de espoliadores das populações pobres, afirmava que ele não poderia ser assim injuriado. Era sim estrangeiro, e se orgulhava de sua pátria, a França, mas tinha no Brasil sua pátria adotiva e ressaltava que sempre lutara para promover melhoramentos à pátria que tão bem lhe tinha acolhido. E que, não obstante fossem muitos aqueles que realmente visavam somente os ganhos financeiros, essa não era sua sina ${ }^{28}$.

Padre Gay trazia em seu discurso uma marca registrada, a retórica de um pároco preocupado com os destinos da região a qual dedicara grande parte de sua vida. E de fato, muito da sua luta se dera em função dessa missão que julgava ter. Mas o cônego de São Borja não fora somente um idealista e tampouco era despossuído de bens. Ao contrário. Seu patrimônio era invejável para um padre do interior da província. Rodrigues comenta que em 1865 ele teria nada menos que nove moradas de casa, duas chácaras onde tinha criação de animais e plantações, além de uma considerável fortuna em livros e de diversos projetos para extração mineral nas imediações, com cálculos precisos de investimentos e possibilidades de lucros (RODRIGUES, 1954, p. 79-80).

Gay, ainda assim, tinha bem claro o que considerava ser sua função de pároco, mas em muitos momentos os interesses políticos também permearam suas ações e convicções, na medida em que sua atuação era de vital importância nas definições eleitorais da região da campanha. Ele articulou contra desafetos ou contra os que lhe atrapalhavam. Compreender sua trajetória passa, invariavelmente, pelo entendimento destas duas faces que as evidências nos trazem, nas entrelinhas dos discursos e na relação destes com as ações concretas que podem ser observadas.

Ele deixou, inquestionavelmente, uma obra vasta e um conjunto documental precioso sobre a realidade social da fronteira em tempos de

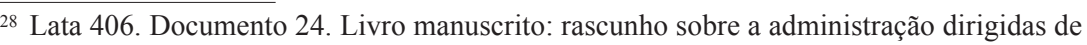
Alegrete e São Borja. 1848-58. 11 nov. 1853. IHGB. São rascunhos do artigo a ser enviado ao Correio do Sul, como réplica. 
Império. Evidentemente, não podemos - e nem nos propusemos a isso - sintetizar sua experiência histórica concreta nesse quadro ainda muito preliminar sobre suas vivências e relações. Todavia, seguramente nos foi dada a oportunidade de abrir novas possibilidades de investigação sobre a riqueza da documentação preservada e da obra ainda pouco explorada dessa figura tão peculiar e curiosa. Acreditamos que possa inspirar muitos pesquisadores que se interessem por essa história da região e pelo século XIX, pois as possibilidades de pesquisa aqui sugeridas estão apenas delineadas.

\section{Referências}

ABRAMSON, Pierre-Luc. Los Falansterios de Santa Catarina In: Las utopias sociales en América Latina em el siglo XIX. Trad. Jorge Alberto. Videla. Cidade do México: Fundo de Cultura Econômica, 1999. p. 205-222.

ARÓSTEGUI, Julio. A Pesquisa Histórica. Teoria e Método. Trad. Andréa Dore. Bauru, SP: Edusc, 2006. 591 p.

BLAKE, Augusto Victorino Alves Sacramento. Diccionario Bibliographico Brazileiro. Rio de Janeiro: Imprensa Nacional, 1898. v. 4. 466 p.

FARINATTI, Luis Augusto Ebling. Confins Meridionais: famílias de elite e sociedade agrária na Fronteira Sul do Brasil (1825-1865). 2007. 519 p. Rio de Janeiro. Tese (Doutorado em História Social) - Universidade Federal do Rio de Janeiro, Rio de Janeiro.

\section{Ficha técnica de arquivos e coleções particulares - IHGB}

GALHARDO, José Emygdio Rodrigues. História da Homeopatia no Brasil. In: INSTITUTO HAHNEMANNIANO DO BRASIL. Livro do $1{ }^{\circ}$ Congresso Brasileiro de Homeopatia. Rio de Janeiro: Instituto Hahnemanniano do Brasil, 1928. p. 259-1014.

GARCIA, Rodolfo. Noticia bio-bibliográfica sobre o Cônego João Pedro Gay. In: GAY, João Pedro. História da república jesuítica do Paraguai: desde o descobrimento do rio da Prata até aos nossos dias, ano de 1861. Rio de Janeiro: Imprensa nacional, 1942. p. v-Xii.

GAY, João Pedro. História da República Jesuita do Paraguai desde o descobrimento do Rio da Prata até os nossos dias, ano de 1861. Rio de Janeiro: Typ. de Domingos Luiz dos Santos, 1863. 342 p.

GUTFREIND, Ieda. A Historiografia rio-grandense. 2. ed. Porto Alegre: Editora da UFRGS, 1998. $162 \mathrm{p}$.

MARTINS, Almir. História de Santa Catarina - Cultura e Folclore. Imbituba: VoxLegem, 2003. $158 \mathrm{p}$.

PINHEIRO, José Feliciano. Anais da Província de São Pedro. 3. ed. Rio de Janeiro: Imprensa Nacional, 1946. 249 p.

RODRIGUES, José Honório. Padre Gay. In: Província de São Pedro. Porto Alegre: Globo, 1954, p. 75-92. 
RUBERT, Arlindo. História da Igreja no Rio Grande do Sul. Vol. II. Porto Alegre: EDIPUCRS, 1998. 325 p.

RUPERT, Arlindo. O Antigo Clero diocesano do Rio Grande do Sul (1737-1910). Santa Maria: Pallotti, 2005. 432 p.

THOMPSON, E. P. A Miséria da Teoria ou um planetário de erros. Trad.: Waltensir Dutra. Rio de Janeiro: Zahar, 1981. 231 p.

TORRES, Luiz Henrique. Historiografia Sul-Rio-Grandense: o lugar das Missões Jesuítico-Guaranis na formação histórica do Rio Grande do Sul (1819-1975). 1997. 208 p. Porto Alegre Tese (Doutorado em História) - Pontifícia Universidade Católica do Rio Grande do Sul, Porto Alegre.

VILLAS-BOAS, Pedro. Notas de Bibliografia Sul-Rio-Grandense. Porto Alegre: Instituto Estadual do Livro, 1974. 347 p.

WEBER, Beatriz Teixeira. Uma Introdução à História da Homeopatia no Brasil In: MILDER, Saul Eduardo Seiguer. Recortes da História Brasileira. Porto Alegre: Martins Livreiro, 2008. p. 101-111. 